\title{
The Arab Revolutions: The Emergence of a New Political Subjectivity
}

Sari Hanafi

(American University of Beirut, Beirut, Lebanon)

\section{Introduction}

Now is the time of the furnaces, and only light should be seen.1)

Over the past year the Arab World has witnessed regime change in Tunisia, Egypt and Libya; Arab citizen revolts are underway in Syria, Bahrain and Yemen; and different levels of reform initiatives can be found in Morocco, ${ }^{2}$ ) Algeria3) and Jordan.4) These processes

1) Jose Marti, quoted in Che Guevara, "Message to the Tricontinental" [April 1967], Resurrecting a revolutionary cinema. The hour of the furnaces, http://edchannels.org/ writings/RC001/pdf/Furnaces_RC001.pdf/.

2) The new Moroccan constitution, replacing that of 1996, supposedly represents a further step in the direction of establishing a liberal-democratic system and does indeed contain provisions to that effect. For instance, there is now explicit recognition that Morocco is a 'parliamentary constitutional monarchy,' that national identity is pluralistic and not simply Arab and Muslim, and that, crucially, the figure of the king is no longer 'sacred,' but simply inviolable. In 
cannot be captured by Orientalist terms such as 'Arab Spring,'5) 'Arab unrest' or 'the Facebook Revolution.' These labels do not account for the radical transformation in politics and values that the Arab World is undertaking. The 'Arab revolutions,' as people in this region opt to call them, have already inspired protests in Israel, Mexico, Afghanistan and beyond. The fate of these popular uprisings remains in the balance, but it is all too clear that they have produced the most dramatic changes in the region since the mid-twentieth century, which marked the end of the colonial era.

addition, parliament's powers have been increased. See E. Dalmasso and F. Cavatorta, Jadaliyya, http://www.jadaliyya.com/pages/index/2365/the-never-endingstory_protests-and-constitutions/.

3) Pressure from protestors in Algeria led to the lifting of the state of emergency in February 2011 as part of a package of concessions by the government.

4) The reform consists of the following. (1) The establishment of a constitutional court to monitor the constitutionality of laws and regulations. (2) The establishment of an independent commission to oversee elections instead of the Ministry of Interior which has previously been in charge of the electoral process. All electoral contestations will be referred to the judiciary instead of parliament. (3) The enhancement of civil liberties, including the criminalization of any infringement on rights and public freedoms or on the sanctity of Jordanians' private life; the prohibition of torture in any form; and a declaration that all forms of communication between citizens shall be treated as secret and not subject to censorship, suspension or confiscation, except by judicial order. (4) The limitation of the government's ability to issue temporary laws during the absence of parliament, a practice that governments exercised at will in the past. (5) The limitation of the State Security Court's jurisdiction to cases of high treason, espionage and terrorism, with citizens being otherwise tried in civilian courts; this includes ministers who were previously tried by a parliamentary high tribunal. (6) The limitation of the government's ability to dissolve parliament without having to resign itself Marwan, Muasher, Jordan's proposed constitutional amendments-a first step in the right direction (The Carnegie Middle East Program, 2011).

5) For a criticism of this term, see Rami Khouri, "Drop the Orientalist Term "Arab Spring," The Daily Star Lebanon, August 17, 2011, http://www.dailystar.comlb/Opinion/ Columnist/2011/Aug-17/Drop-the-Orientalist-term-Arab-Spring.ashx\#ixzzlVGW806O8/. 
The significance of these revolutions resides in the realization of social and democratic demands. One should read them as continuities in a long history of protest in the region rather than a total rupture. One should keep in mind, for example, that the Tunisian uprising had its beginnings in Gafsa, three years ago, in a protest over bread prices and unemployment. Also, in 2009, dissident bloggers and Facebook users in the Tunisian city of Jarjis demanded the release of political prisoners and called for freedom of expression. In the cases of both Tunisia and Egypt, the revolutions were aimed at achieving social and democratic reform, initiated by unemployed university graduates and workers who independently organized themselves into unions.6)

In the name of justice, dignity and freedom (freedom to join political groups and parties, freedom of expression, and freedom of religious practice), protestors fought against unemployment and grew hostile towards neoliberal and neo-patrimonial regimes.

Beyond the structural conditions that drove the forces of these revolutions, they may also be interpreted in different ways in terms of their cultural power and the power of symbols. The sheer theatre of the drama that unfolded in Tunisia caused a domino effect in other Arab countries, starting in Egypt. In this setting, the revolutionary youth are

6) I qualified these unions as 'autonomous' to contrast them with the official workers' unions which are often co-opted by the regime. In this regard, see M. Duboc, "La contestation sociale en Égypte depuis 2004-précarisation et mobilization locale des ouvriers de l'industrie textile," RevueTiers monde, numbero hors series; E. Longuenesse, Professions et société au Proche-Orient. Déclin des élites et crise des classes moyennes (Rennes: Presses Universitaires de Rennes, 2007); and F. Clément, "Élections ouvrières: entre fraude et chasse aux 'Frères masques," in Chroniques égyptienne, eds. E. Klaus and C. Hassabo (Cairo: Cedej, 2007), 59-86. 
educated individuals-men and women, Muslims and Christians-who used all forms of contemporary technology, such as mobile phones and laptop computers, as well as hand-made signs and banners, to convey their message and spread their demands. The carnivalesque performances, particularly those in al-Tahrir Square, Cairo, were replete with chants, music, comedic acts, humour and sarcasm. In these essentially indigenous revolutions (except for Libya's), no sign of the U.S. Agency for International Development (USAID) or other international agencies was found; nor were there requests made to such agencies for the funding of glossy placards, brochures or workshops in five-star hotels.7) In complete contrast, official feasts were full of the supporters of the calcified regime who came with their horses and their camels, bricks, knives and sticks.

The intention in this article is to reveal the people in the popular slogan 'the people want the fall of the regime.' It aims to identify the actors involved in the revolution, namely the youth and the labour movement. By doing so, it will explore the new political subjectivity ushered in by these revolutions, in a specific form of individuality that will be labelled reflexive individualism. One cannot understand this subjectivity of the revolutionaries without addressing the complexity of the political-judicial structure (and the regime's constant use of the state of exception) and the social structure (socioeconomic and demographic factors) in this region that push actors to revolt.8) As Yasine al-Hafez once singled out social structures

7) On the carnivalesque, see M. Bakhtin, Rabelais and his world (Bloomington, IA: Indiana University Press, 1984).

8) The Agambian concept of state of exception refers to the capacity of the sovereign to claim anytime the state of exception, i.e., governing by the 
as a medium to explain the 1948 defeat, they will be used here to explain the uprisings.9)

This paper draws mainly upon eighteen in-depth interviews conducted by the author during 2011 with activists who participated in the revolutions in Tunisia (two), Egypt (seven), Libya (one) and Syria (eight). In addition, it is informed by many informal meetings the author had with many activists.

\section{The Context: Some Facts}

Although this paper is more focused on how the revolutions happened than why, it is important to highlight some socio-economic and demographic factors. The performance of the state in the Arab region has been flawed and volatile, especially as of 2007 , when a substantial drop in gross domestic product (GDP) growth and GDP per capita growth occurred (it dropped from around 3\% to less than 0.3\%). Furthermore, the region lags behind other regions such as East Asia. ${ }^{10}$ )

According to the Economist Intelligence Unit, many Arab countries (Jordan, Algeria and Saudi Arabia) have an unemployment rate in excess of $10 \%$, and in Tunisia in particular it rose to $13 \% .{ }^{11)}$ Corruption in

suspension of law rather than by the force of law. For more analytical analysis of the use of the state of exception in the Arab World, see Sari Hanafi, ed., The State of Exception and Resistance in the Arab World (Beirut: Center for Arab Unity Studies, 2010).

9) Fadi Bradawil, "Ufūl al-Iktiāb: mulāḥaẓātān hawla al-thawrāt al-arabiȳ ah al-rā hinah" [Two notes about the Arab revolutions], Majallat al-Dirāsāt al-Filastı $\bar{n} \imath \bar{y}$ ah, 88 (2011): 65.

10) Navtej Dhillon, and Tarik Yousef, Generation in waiting: the unfulfilled promise of young people in the Middle East (Brookings Institution Press, 2011). 


\section{Sari Hanafi}

the Arab World is clearly very high: half of the countries are rated above 80 in the Corruption Perceptions Index (CPI).

Four characteristics are commonly identified with the Arab World. The first concerns the unemployment rate, which is much higher among youth. The rate increased from $10 \%$ for the average population to over $20 \%$ for the young population in many Arab countries (20.1\% for Syria, $28 \%$ for Egypt and $30 \%$ for Tunisia), reaching more than $40 \%$ for Algeria and the Palestinian territories. ${ }^{12)}$ This rate also registered increases among highly qualified youth (especially in Jordan and Egypt), especially female youth.13)

The second factor concerns the rampant inequality within Arab societies. According to Marcus Marktanner this inequality has risen markedly: the difference between the Estimated Household Income Inequality (EHII) in the 1980s versus that in the 1990s for the Middle East North Africa $($ MENA) region was 3.8 (Tunisia $=10.0$, Egypt $=3.2$ )-higher than the world average (3.2). ${ }^{14)}$ One should not forget that the so-called 'Tunisian economic miracle,' a phrase frequently used by the International Monetary Fund (IMF) and The World Bank, refers to the capital and northern coastal cities, but not the interior of Tunisia or the south. The deregulation of the property (real estate) market, the absence of social housing projects and the absence of protection for tenants who rent has a tremendous impact on the

11) Economist Intelligence Unit, Spring Tide or Will the Arab Risings Yield Democracy, Dictatorship or Disorder? http://pages.eiu.com/rs/eiu2/images/Arab_ Spring_Tide_Whitepaper_Jun2011.pdf.

12) Ibid., 22.

13) Ibid., 22-25.

14) Marcus Marktanner, "The economic causes of the Arab uprising." Paper presented at a workshop at the American University of Beirut, Beirut, Lebanon, 2011. 
young. The increase in inequality has worsened since 2007 in the wake of what Marktanner called a 'Triple F crisis' (fuel, food and financial). ${ }^{15)}$ Rising fuel and food prices rendered universal subsidy systems no longer financeable. Due to the ending of state food subsidies (pushed by the IMF) and the inelasticity of fuel and food prices and consumption, and the fact that poor households spend greater proportions of their income on food and fuel, real income inequality has accelerated in recent years far beyond the nominal one. The global financial crisis has, moreover, reduced receipts from remittances, affecting many vulnerable households.16) As Michael Burawoy has noted, we are in an era in which exploitation and societal exclusion (social, urban and economic) comprise the main phenomenon that strikes most societies and the sweeping impact of the exclusion has made the exclusion a sort of privilege, especially for a young generation. ${ }^{17)}$

The third factor is that the Arab region, specifically the Arab East, is considered an area particularly vulnerable to the negative impacts of climate change. This is even more significant given that the Arab East is also one of the most volatile regions in the world in terms of inter-and intrastate conflict and instability. The United Nations Development Programme's Arab Human Development Report considers the relationship between resource pressures, environmental sustainability and human security in the Arab region as a matter of utmost importance. 18)

15) Ibid.

16) Ibid.

17) Michael Buroway, (speech given to the European Sociological Association Congress in Geneva, Switzerland, September 23, 2011).

18) United Nations Development Programme, Arab human development report (Washington, DC: UNDP, 2009). Smith and Vivekananda, from Alert International, drew up a list of states at risk based on the identification of two types of risk. 
Syria is also facing climate extremes in the form of successive droughts and migration from the northeast. Since 2007, Syria's northeast (particularly 150 villages in the districts of Hasakeh and Raqqa) has suffered from the worst drought to hit the country in five decades, combined with an increase in the temperature in March and April.

Finally, the Arab region is a conflict-ridden one that deters investors from risking their capital there. In addition, immense resources are often used for buying arms at the expense of healthcare and education. While these economic indicators are dramatically negative, many socio-cultural factors are relatively positive. Y. Courbage and E. Todd pointed out three dynamics:19) the rapid increase in literacy,20) particularly among women; a falling birth rate;21) and a significant decline in the

First, the Arab states that face a high risk of armed conflict as an indirect consequence of climate change include Algeria, Djibouti, Eritrea, Iraq, the Occupied Territories, Jordan, Lebanon, Somalia, Somaliland, Sudan and Syria. Second, the Arab states that face the potential for political instability as a knock-on consequence of climate change are Egypt, Libya, Mauritania, Morocco, Saudi Arabia, Western Sahara and Yemen. Smith and Vivekananda (2007).

19) Y. Courbage, and E. Todd, "Le Rendez-vous des Civilizations," in A Convergence of Civilizations: The Transformation of Muslim Societies, eds. Y.Courbage and E. Todd (New York, NY: Columbia University Press, 2007).

20) Ninety per cent across the board, except in Morocco, where it is $81 \%$. J.L.S. Barbin, "The Arab Spring and demography: the revolutionary power of youth," 2011. http://en.qantara.de/The-Revolutionary-Power-of-Youth/16590c16844i0p/ index.html/.

21) Impressive declines in fertility have been recorded in the Arab region as a result of increased school enrollment among girls, stronger participation of women in the labour force and delayed marriage. The decline in fertility simultaneously affected two-thirds of Arab countries. See Courbage and Todd, "Le Rendez-vous." According to the 2008 revision, the unweighted average total fertility rate for the Arab countries declined from 6.2 live births per woman in 1980-1985 to 3.3 in 2005-2010 (compared with 2.6 at world level during that latter period), consequently reshaping the age structure of the population of the Arab region. 
widespread custom of endogamy, or marriage between first cousins. Although there is a reported observation of a 'youth bulge' (an aboveaverage proportion of young people aged between fifteen and 25 years in a society), this bulge will not be maintained by highly qualified young people whose fertility rate has fallen significantly.

\section{Complexity of the authoritarian regime}

According to the Economist Intelligence Unit, the majority of Arab countries are governed by authoritarian regimes, and only three countries (Lebanon, the Palestinian territories and Iraq) have been classified as having hybrid or pluralist regimes.22) The Arab World notably avoided the waves of democratization that took place in Latin America, Southern and Eastern Europe, and parts of Sub-Saharan Africa and Asia in the 1970s, 1980s and 1990s.23) Other organizations such as the Arab Reform Initiative (ARI) and Freedom House established similar indices using similar methodologies. These indices prove helpful in tracking the micro-transformations of the Arab World and in determining which state has undergone governance change and moved towards the rule of law. However, they fail to examine the impact of events on the following levels.

United Nations Economic and Social Commission on Western Asia, Population in the Arab World declines, http://www.alarabiya.net/articles/.

22) Economist Intelligence Unit, Spring Tide.

23) Ibid. 


\section{First level}

The relationship between the legal and the political, i.e. how the rule of law, when it exists, does not hinder the law of rules. The presidents of Syria, Tunisia and Egypt acted as sovereigns making ultimate decisions over whether to enact a law or to suspend it, whether to 'take life or let live.' They violated their people's rights-arresting, torturing, murdering and ruining their countries economically. The 'state of exception' (see below) has been particularly felt in the peripheries, often outside the capital, in spaces of exception, where the state only served as a security apparatus or as a surveillance machine over foreign aid dispersal. There, in places such as Daraa, Banias and Homs in Syria, local identities emerged and uprisings started.

Arab revolutions have shown that a reform process based on changing laws and regulations without a real political restructuring is a hollow process. The state of emergency, as one of the forms of the state of exception, can be seen as more than a legal doctrine, and rather as a governmental structure. ${ }^{24)}$ In Syria, the revocation of the emergency law and abolition of its associated security courts in April 2011 have not reduced state repression. Giorgio Agamben offered a compelling argument for how this ruse works when he discerned that both the Italian Fascist and German Nazi regimes operated without cancelling their respective constitutions through a paradigm that has been defined as a 'dual state,' whereby a further structure that was not legally formalized was added to the constitutional

24) J. Reynolds, "Emergency, Governmentality, and the Arab Spring," Jadaliyya 14 August 2011. 
settings by virtue of a 'state of exception.'25) Dismantling the state security apparatus thus requires regime change and not only issuing a new set of laws, as demonstrated in the case of Syria.

\section{Second level}

These indices failed to uncover the complexity of the state apparatus. The authoritarian states have governed through their heavy 'right hand', to borrow this concept from Bourdieu, using their security and repressive apparatus and exemplified by the alliance between bureaucrats and crony capitalists. ${ }^{26)}$ Up to 2000, the population has 'borne' or tolerated this because the same state also has a 'left hand' which provides public goods to a large portion of the population, it being a remnant of the welfare state. Pierre Bourdieu's powerful metaphor breaks with the unitary vision of 'the state' as an organizational monolith and explains the internal divisions and struggles it harbours. The problem that faces many Arab societies is that the neoliberal, deregulatory system of the right hand no longer wants to pay for the left hand. These cutbacks in the 'welfare' state become without precedent with the acute economic crisis. For instance, it is shocking for those who have visited Libya to notice the extent to which this wealthy country has a poor infrastructure outside Tripoli and to witness the harsh level of poverty. The rentier economy was incapable of generating a surplus

25) G. Agamben, Homo Sacer: Sovereign Power and Bare Life, trans. Daniel Heller-Roazen (Stanford, CA: Stanford University Press, 1998).

26) P. Bourdieu, Acts of Resistance: Against the Tyranny of the Market, trans. Richard Nice (New York, NY: New Press, 1999). 
to subsidize the deprived strata of the population. ${ }^{27)}$

The Arab youth feel that they have become a Homo sacer, in the sense of Agamben, which means that this was the revolt of 'bare lives,' of defenceless hungry bodies that the regime has stripped of political identity and of the right to belong to such groups as the Islamic Renaissance Movement 'al-Nahda', the Tunisian Communist Labor Party, and the Muslim brotherhood.

\section{State of exception}

In a book that I edited in 2010 called The State of Exception and Resistance in the Arab World, the Tunisian sociologist Mohsen Bouazizi wrote about the silent expressions of opposition among the Tunisian youth and how indifference and carelessness are deployed against the regime. ${ }^{28)}$ But what Bouazizi did not see then is how Mohamed Bouazizi, who is from the same city as Mohsen-Sidi Bouzid-was alienated from the social structures and thus made to become, echoing Touraine's words, a subject: the driving force of a social movement. ${ }^{29)}$

Mohamed's body, like that of other young Tunisians, was a target for the oppressive regime and its disciplinary authority, which aimed to strip it of its political identity. Thus by committing protest-suicide,

27) Tawfic, Al-Madini, "Rabii al-thawrat al-dimocratiyya al-Arabiyya" [The Spring of the Arab revolutions], al-mustaqbal al-Arabi (2011).

28) Moshen Bouazizi, "Sociology of the Indifference: From Indifference to the Free Aggression in Tunisia," The State of Exception and Resistance in the Arab World, ed. Sari Hanafi (Beirut: Center for Arab Unity Studies, 2010).

29) Alain Touraine, Critique of Modernity (Oxford: Basil Blackwell, 1995). 
Mohamed created a pattern of resistance whose effectiveness was achieved at the moment of the body's self-immolation. We are at a moment similar to the time when the Palestinian resistance in the occupied territories challenged the sovereign authority that sought to turn them into humiliated subjects who could be killed without any recognition, i.e. death without value. Mohamed Bouazizi and his fellows, who died by committing suicide, became actors who deliberately sacrificed themselves, and by that act, inverted the relationship with the sovereign authority.

The Syrian revolution has gone through another dynamic. 'State of exception' and bio-politics cannot account for the topographies of cruelty of the Syrian regime. According to the Syrian Observatory of Human Rights, the death of 4342 civilians in the nine months suggests a necropolitics, to echo Achille Mbembe. ${ }^{30)}$ (Mbembe 2003). This Syrian combination between a state of exception, bio-politics and necropolitics has created new conditions that blur the lines between resistance and pacific demonstration, sacrifice and redemption, violence and freedom.

Despite all the technological and imbedded power that Arab regimes have, they are not total institutions that control everything. After all, it is often the case that oppression is a sign of weakness rather than strength, as was seen when the 'mighty' regime of Zine El Abidine Ben Ali in Tunisia could not get the army to follow the

30) Since the revolution and up to January 20, 2012, the Strategic Research and Communication Center reported 4342 Syrians killed, 6159 missing, 15,000 protestors incarcerated and upwards of 12,577 Syrian refugees. Syrian Observatory of Human Rights 2012). Syrian Observatory of Human Rights, http://www. syriahr.com.On necropolitics, see A. Mbembe, "Necropolotics," Public Culture 15, no. 1 (2003): 11-40. 
oppressive rule of the police. The system also failed to silence the opposition, especially in the diasporic community. This offers a ray of hope to all those struggling for democratization-to learn how to use the regimes' weaknesses to produce change in the order.

\section{Actors of the social movements}

While the people literally engaged in the Arab revolutions, two groups of actors played a critical role. The first group included the educated independent youth, combined with political parties and unions that give such movements the needed momentum, organization and mobilization. The second group was composed of labourers, some members of unions, some not. ${ }^{31)}$ Many analysts, deliberately or not, neglect the importance of the latter group and mythically present the youth as classless, middle class and/or nonideological.32) In reality, these revolutions represent emerging social movements that combine the classical form based on social classes with a new form in which the struggle for civil rights prevails.

Youth: new political subjectivity and reflexive individualism

The individuals construct themselves in the space between social integration and disintegration, what Touraine calls commitment and

31) For a compelling description of the constituency of al-Tahrir Square, see Khairi (2011).

32) For a critical assessment of using the ambiguous term of social classes, see J. Kabbanji, "Why have the Tunisian and Egyptian revolutions surprised us?" Iḍāfã t: Arab Journal of Sociology 14 (2011): 9-31. 
non-commitment, armed with the power of reflexivity.33) This individualism, which I refer to as reflexive individualism to distinguish it from neoliberal individualism, is thus not a straightforward anti-patriarchy, anti-tribe, anti-community and anti-political party. It is a type of individualism that involves the constant negotiation of an actor with the existing social structure in order to realize a (partial) emancipation from it. This is an act of self-reference of an agent that recognizes forces of socialization but alters his or her place in the social structure and resists their disciplinary power.

The new political subjectivity of the youth (in addition to the labourers, as will be shown below, and the peasants in the case of Syria), embodied the nation, al-watan. The actors became a source of unification for all the civilians in opposition to the regime and all the people facing the regime, without raising narrower or particularistic claims. Carrying their national flag, the Syrian protestors chanted 'United, united, united, the Syrian people are united'; and the Palestinians called for the end of their division (Fatah versus Hamas and West Bank versus Gaza). Sectarian or religious slogans became morally inferior and unfit for grounding the new political subjectivity. As Challand pointed out, we are in a process of a radical re-imagining, in the sense of Cornelius Castoriadis, of uniting the effort of the nation and of self-organization, that is, opposing, from one side, the classical fragmentation and atomization of the non-governmental organizations' (NGOs) sphere, and from the other side, the violent political tradition of some political parties.34) If there is an ideology for this radical

33) Touraine, Critique of Modernity, 285.

34) B. Challand, Palestinian Civil Society: Foreign Donors and the Power to 


\section{Sari Hanafi}

re-imagination it is that they used a non-violent mode of action that gives them inexhaustible sources.

This individuality used in the new political subjectivity is not a neo-liberal one that used to be promoted by NGOs and other formalized civil society organizations. These organizations are too comfortable to mobilize. However, what about the human rights associations and civil organizations and NGOs? Many donors and international organizations limited their view of civil society to the 'depoliticized' and professionalized associations, and believed they were the ones that would carry the winds of change. These associations played an auxiliary role to the syndicates and opposition parties. This role consisted of disseminating information about casualties and death tolls, urging international powers, at both official and unofficial levels, to take firm positions against authoritarian regimes. However, two features were missing. First, the fact that most of these organizations are non-membership organizations (except human rights organizations in Tunisia and Morocco) and they have a very feeble capacity to mobilize the public. Second, the synergy between the four pillars of civil society: syndicates, (oppositional) parties, independent press and NGOs, are missing. Donors that focused only on NGOs have fostered, among other factors, the emergence of a globalized elite whose connection to the local society is very loose, and which has led to an inflation of NGOs, and to a weakening of the syndicates and parties that historically fed the NGOs with fresh talent. ${ }^{35)}$ This globalized elite has embodied the figure of the Homo economicus, as Benoit Challand eloquently put it:

Promote and Exclude (London: Routledge, 2009).

35) Hanaafi and Tabar 2005. 
[these organizations] are precisely geared at producing new subjectivities, of 'active' citizens educated in the dominant language of development, made of 'empowerment' and other projects geared at molding good citizens. These are in reality thought as rational homineso economici, taught to weigh the costs and benefits of each individual action, and who might be critical but still subject to the global neoliberal dominant order, consumers of global goods, and 'beneficiaries' of democracy assistance programs. The neoliberal agenda, premised on a methodological individualism, and other democratization or good governance programs often overlook, not to say actively deny, the defense of collective rights (such as workers' rights, right to self-determination) unless geared at supporting minorities (typically in terms of gender or religious minorities). ${ }^{36)}$

This neoliberal individualism was promoted by (the late) capitalism that has sought to shift society from total state to total individual. ${ }^{37)}$ A television reality show broadcast on one of the American channels, on 2 November 2011, featured a debate on ageing, mercy death and the costs for the social security budget of elderly ill people in their protracted last stage of life. When someone exposed a story of a man who had a prolonged coma, people from the audience started screaming 'let him die -.let him die ...'. This is what I call a neoliberal individualism or the notion of a total individual that is in dissonance with the collective identity embodied by the nation or family.

In contrast to this form of individualism, the political subjectivity of the Arab revolutionary is formed and shaped both within and across the shadowy edges of political institutions and their production of legitimacy and knowledge. For instance, some activists in al-Tahrir Square that I

36) Challand (2009).

37) T. Todorov, "La Tyrannie de l'Individu," Le Monde, March 28, 2011, 18. 
interviewed are members of the Muslim Brotherhood, but they also criticized its actions and how quickly it entered into a dialogue with the old regime. In the same vein, a Nasserist activist declared to me that she and her group in al-Tahrir Square did not reply to phone calls from the headquarters of their political party for fear that they would impose orders and slogans that they might not like.

Many studies have shown that there is a close link between patrilinear family structures and authoritarian political systems. ${ }^{38)}$ Without fully equating modernization to eventual democratization, the ongoing change in family structure may be a contributing factor in the Arab revolutions. Given the literacy, exogamy and decrease in fertility rates, the Arab societies were the reference point and context, as argued above, for the individual to become an important autonomous entity. The political subjectivity is expressed not only by toppling the regime, but also by changing the individual. Challand brings the example of cleaning al-Tahrir Square and the surrounding streets after the end of the protests as a sign of struggling against the past sense of collective inertia and the largely apathetic usage of the public sphere. ${ }^{39)}$

Cyberspace comes to empower this reflexive individualism. Each demonstrator became a 'journalist' carrying a mobile phone and filming state repression, thereby bypassing the official media. The success of the protestors in launching the revolution can be attributed to the fact that they use governmentality, the grammar of which is unknown to the state governmentality. For instance, the security apparatus that used to control national mass media, phone and, to an extent, the

38) Courbage and Todd, "Le Rendez-vous."

39) Challand (2009). 
internet has not been able to control the social media that has been used through different proxies, bypassing the state filtering efforts. While this apparatus has controlled the public sphere, the public cyberspace, with the help of the Arab television channels and alternative media, has been a very important space for activism and mobilization.

Take the case of the high-risk political activism of S.F. interviewed in August 2011. S.F. is a 22-year-old Syrian student studying civil engineering. His family is middle class with his father employed as an engineer. He says:

I have never been a member of any political party. [‥] My family is literally an apolitical one. [..] We have never been supporters of the regime nor against it. After one month of reflection, I decided to open an account on Facebook. I use a nickname and I become informed about the place and time of protests in Damascus. I was afraid to join protests on the street. Despite the fact I have never prayed, I went to the mosque and I joined the demonstration from there. I did it three times. I did not tell my family but one of my relatives saw me and informed my parents. My parents gently tried to persuade me not to go to demonstration. When I refused, my parents became so tough with me. I have a wealthy friend who lives alone. He accepted that I live with him for a few weeks. I left home. I kept calling them once every day to assure them that I was safe. Two weeks ago I was arrested on the street while demonstrating. The Syrian intelligence asked me how I knew about the place and the time of the demonstration. I told them from internet and Al Jazeera TV. They asked me to open my Facebook or twitter account. Thank God! I have it with a nickname. They beat me on and off for one day. I kept denying having a social media account. They asked me about my religiosity. I told them that I am not

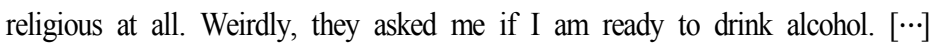
I was released after three days. 
When I asked S.F. about the motivations behind his activism, he replied:

I want freedom for me and for my people. Tunisians and Egyptians are not better than us. We, Syrians, have provided intellectual debates for the whole Arab World. I cannot bear the idea that someone in power for 11 years and his dad before him for 30 years. In addition, the people around the regime are so corrupted. My engineer friends have told me many stories about how much they would pay to buy off [the authorities] every time they want to get a construction contract from the state. The regime keep talking about the 'new Syria', but we want new Syrian citizens.

When I asked him if political pluralism is established in Syria, would he adhere to a political party, he replied: "I don't know. I hope I find a party which will bring social justice to people and generate employment for youth. I don't like conservative parties. I will not vote for religious people to become politicians."

The case of S.F. clearly illustrates the capacity of the individual to negotiate his or her actions with his family and his environment. His political subjectivity is expressed in the form of citizenship and the utopia (in Manheimi's sense of word) of being a new Syrian citizen.40) His motivation is not ideology, but his commitment showed real claims to freedom, social justice and secularism.

Two factors will influence tremendously the new political subjectivity based on reflexive individualism: the role of the external forces and the media.

40) Also very interesting is how many times Wael Ghonaim in his Facebook account used the word 'dream'. In the words of Jeffery Alexander: 'Ghonaim insisted to his fellow Egyptians that dreaming is a civil obligation.' (Alexander 2011, p. 66). 
Faced with this subjectivity and peaceful protests, foreign powers (especially the Western ones) tried to 'orient' the process and the future new elite formation. In spite of the importance of the international community in effecting the isolation of the ousted regimes, these revolutions are chiefly driven by very reflexive local actors. Suspicion comes from two groups. The first is composed of those who support these regimes that often highlight a Western plot to weaken the Arab World by these revolutions, stating especially the case of Syria and Libya as two regimes that have for long resisted Western imperialism. Faced with the Western intervention in Libya, the Arab nationalists and leftists have been divided over this intervention: between those who support it and those who consider it as a new colonial enterprise. However, in my opinion, we are witnessing a reflexivity in the form of a new dynamic of construction of otherness which is less essentialist and binary, i.e. West versus Islam and Islamic people, to a more nuanced and dynamic otherness. In the case of Syria, the debate is often expressed in terms of conspiracy: Syrian regime supporters coin the opposition as pro-American or anti-resistance, while the latter branded the former as sectarian and vehicles of an Iranian agenda. Rare are those who discuss the two positions in terms of those who believe in the possibility of reforming the Syrian regime and those who do not.

The second group comprises those who have underestimated the agency of the Arab revolutionaries. In his lecture at the American University of Beirut on 1 April 2011, the philosopher and theologist Tareq Ramadan stated that Arab politicized bloggers and some of those who use Facebook and Twitter are trained by the US State Department, a claim that was not confirmed or backed by any evidence.41) 
Concerning the mass media, its pluralism has enabled the new political subjectivity of individuals. The phenomenon of Al Jazeera contributed to the creation of an Arab public sphere, in a Habermasian sense, wherein dialogue, rational, critical, and deliberative debates emerge and evade control by the national regimes. For instance, El Oifi argues that while Al Jazeera seems to be part of the American recipe for media liberalism that is capable of producing political moderation, it indeed gave voices to individuals and groups to produce the most effective critique of American policy.42) While mass media, albeit less important, were a means to report the events, the national television stations were completely misinforming their publics. On January 26, 2011, Egyptian television screened a cooking programme, as if in complete oblivion of what filled the streets. Alternative media, as well as channels such as Al Jazeera, Al Arabiya, BBC Arabic and France 24 transmitted images sent to them by activist mobiles, providing information and analysis.43) I should stress that Al Jazeera turned from the 'principal of non-interference' in internal Arab affairs to a stance of 'solidarity' with Arab public grievances. ${ }^{44)}$ This is why 'mediology', to borrow Debray's terminology, is a form of new ideology dictated not by intellectuals and philosophers,

41) Tareq Ramadan, (speech delivered at American University of Beirut on April 1, 2011).

42) Mohammed El-Oifi, 'L'Opinion Publique Arabe entre Logiques étatiques et Solidarities Transnationales." Raisons Politiques 3, no.19 (2005): 68.

43) Tania Al-Khoury, "Kulonashohoud 'ayan: rabii al-Arab bi al-sowarwa al-harb al-Ilekitroniyya" [We are all witness: the Arab Spring in image and the cyberwar], Majallat al-dirast al-falastiniyya 88 (2011): 122-132.

44) The solidarity position (qualified by some as lacking professionalism and neutrality), however, is debatable, yet very instrumental in the Egyptian, Libyan and Syrian cases. 
but by pluralistic actors who are shaping and influencing the new political subjectivity of the revolutionaries. ${ }^{45)}$

\section{The Importance of the Labour Movement}

In Tunisia, Mohamed Bouazizi's self-immolation sparked an uprising that began as an unorganized and spontaneous event, but which was soon taken over by labour unions. Here again there are different degrees of reflexivity. The General Union of Tunisian Workers (UGTT) was masterful in dealing with the regime. In northern Tunisia, especially in the capital, Tunis, the leaders of the union were negotiating with the regime (low reflexivity) while their counterparts in the south were opposing it (higher flexivity). The Bar Association, with its large force of mobilization in contrast with NGOs, also played an important role in widening the age group of protesters from youth to all ages, and in spreading it from the peripheries to the capital. It is also important to note the prominent role of lawyers, and even judges, in social movements across the Arab and Islamic world, most obviously Egypt and Pakistan.

As for Egypt, the revolution was sparked by the April $6^{\text {th }}$ Movement that began as a youth group acting in solidarity with the labour strikes in al-Mahalla al-Kubra in 2008.46) However, the role of labour movements dates back to much earlier than the youth movement. Paul Amar pointed out that:

45) R. Debray, Cours de Mediologiegenerale (Paris: Gallimard, 1991).

46) Mona Abaza, "On Recent Social Protests in Egypt: A Success Story in Spite of the Absence of Political Parties," The State of Exception and Resistance in the Arab World, ed. Sari Hanafi (Beirut: Center for Arab Unity Studies, 2010). 
2009 and 2010 were marked by mass national strikes, nation-wide sit-ins, and visible labour protests often in the same locations that spawned this 2011 uprising. Moreover, the rural areas have been rising up against the government's efforts to evict small farmers from their lands and opposed the regime's attempts to re-create the vast landowner fiefdoms that defined the countryside during the Ottoman and British Colonial periods. [‥] In 2008 and in December 2010 we saw the first independent public sector unions emerge. Only one month later, 2011 clusters of unions from most major industrial towns gathered to form an Independent Trade Union Federation.47)

The Egyptian revolution was triggered by the mobilization of the April 6th Movement and the Information Technology group, led by Khaled Said. Both groups used blogs, Facebook, Twitter and SMS to mobilize thousands of demonstrators on January 25 . With the help of the political opposition (particularly the Muslim Brotherhood) they reached millions of protestors in al-Tahrir Square in Cairo, Alexandria, Zakazik, Mansoura, etcetera. In addition to their role in all these cities, in Suez the workers' demonstrations led by independent unions initiated the protest there and were the first in the revolution to claim responsibility for the overthrow of the Hosni Mubarak regime.

\section{Reflexive Islamism}

We are in a period of revolutions where political and civil rights supersede (but do not replace) the ideological. Arab regimes as well as some Arab and Western scholars and journalists thought that the 'Arab street' was chaotic, passionate and 'mobilizable' only by political Islam.48)

47) Paul Amar, "Why Mubarak is out February 1, 2011," Bullybloggers. 
The Yemeni, Syrian, Libyan, Tunisian and Egyptian cases show the importance of Islamic movements, yet the success of the first stage of the revolutions can only be attributed to the alliances with other oppositional groups.49) Undergoing internal transformations, the Muslim Brotherhood (and to certain extent the Salafists) raised slogans that go beyond the simplistic ('Islam is the solution') towards freedom and democracy and concrete claims. Thus, we are in an era of post-Islamism in the sense of a new form of reflexive Islamism, whose leaders have declared constantly their desire for pluralism and respect for freedom of expression. This reflexivity allowed a revolutionary language and political symbols that have referred to democracy, social justice and dignity rather than religious slogans.

Several members of the Muslim Brotherhood and al-Nahda declared they were in favour neither of a secular state nor of a religious one. The use of the notion of dawla madaneyya (civil state) is again a self-referencing exercise which raises a problem that terms are not yet determined. In spite of this blurring of terminology and declarations of some Islamic leaders, there is no reason for many Westerner leaders to consider the newly stated position of the Muslim Brotherhood as a smokescreen for a long-term objective of establishing an Islamic state governed by the strict application of sharia (Islamic law). ${ }^{50)}$

As such, those who argue for the cultural specificity and exceptionalism

48) For instance, see D. F. Eickelman" "The Arab 'Street' and the Middle East's Democracy Seficit," Naval War College Review 40, no.4 (2002): 39-48. For a critique of the usage of the Arab Street, see El Oifi (2005).

49) Asef Bayat, "Egypt, and the Post-Islamist Middle East," Open Democracy, Khaled Hroub, "Arab Third Way: Beyond Dictators and Islamists," Open Democracy.

50) Economist Intelligence Unit, Spring Tide. 


\section{Sari Hanafi}

of the region no longer have a valid argument. The consequences of exceptionalism are regarded as a digression from the real debate on societies, politics and culture in the Arab World.51) One question I have been debating with my students for the past two years in my course on transitional justice at AUB is whether freedom and democracy are universal aspirations or Western values not transferable as such to other societies. My students always brought up the case of the Arab World as living proof that not all people, regardless of culture and religion, aspire to being free and living under the rule of law. For them, the people of Muslim countries with autocratic or theocratic regimes are just content to live that way, under the stick of dictatorship and/or sharia. What we have been witnessing in Tunisia and Egypt settles that!52) I fully agree with Slavoj Zizek that what is now required is a universalistic position of solidarity. ${ }^{53)}$ People's aspirations for democracy and freedom are universal objectives.

\section{Conclusion}

The Arab World is on the verge of a new phase in its history. Revolutions sometimes end up as something different from what their supporters imagined they would be. The antagonism between the people and the dictatorship is still the most important dynamic, but

51) J. Kabbanji, "Why have the Tunisian and Egyptian revolutions surprised us?" Id âfàt: Arab Journal of Sociology 14 (2011): 9-31.

52) See also Badawi and Makdisi (2010), who show the falsity of the argument that religion explains the democracy deficit in the Arab World; and the criticism of Challand (2009) of the idea of a civil society deficit in Arab-Islamic areas.

53) Slavoj Zizek, interview on Al Jazeera, February 5, 2011. 
one should watch carefully the active role of the military and the conflicting views within elite groups on these revolutions.

This article has argued that the revolution was driven mainly by very 'reflexive' youth and labourers and cannot be understood as Facebookdriven protest waves. There are behind-the-scenes of these waves; indeed, there are huge structural and economic forces and institutional realignments at work. ${ }^{54)}$ We are witnessing the twilight of American hegemony in the region. In spite of the importance of the Western countries in isolating the ousted regimes, these revolutions are chiefly driven by the local actors. However, U.S. foreign policy seeks to influence the process. Its policy is not a realism- nor an idealism-based one, but should be read in the light of territoriality, expediency and utilitarianism.

In contrast with the Eastern and Central European revolutions, the reflexive individualism in the Arab revolutions makes it difficult to have a unified opposition leadership. There are no leaders among the self-appointed NGO leaders, nor among political party leaders, nor among tribal sheikhs. Rather, we are witnessing post-Leninist revolutions without leaders (à la the French Revolution), a sort of fragmentation without organization, although over time this has been improved in Yemen and Syria.

The effects of these revolutions are multiple and go beyond toppling the political regime to generate new values. Mohamed Bamyeh coined the term 'of the new patriotism' to describe how these revolutions are transforming the sense of Arab nationalism from 'a project that was assumed to require being represented by leaders or parties, to a

54) Amar, "Why Mubarak Is Out." 2011. 
popular practice, in which patriotism remains concrete and leaderless, expressed largely as a sense of convivial commonness.' 55 ) The role of Al Jazeera television has undeniably been significant in generating a common Arab space and in fostering an Arab public sphere. By extrapolation, the Arab-Israeli conflict was not completely absent from the mind of the protestors. In interviews I conducted, protestors repeatedly used the word 'dignity'56) and/or 'Arab dignity', something they had been denied by the ousted regimes. Both Egyptian and Tunisian regimes, being part of what is called the 'axis of moderation,' had a political discourse that was deeply at odds with popular feelings, which saw their regimes' moderation as a green light for Israel's colonial project and the siege of Gaza.57) I was surprised to see that even in a pro-government newspaper like al-Ahram, there was criticism of Mubarak for having received Benjamin Netanyahu on January 4, 2011, the day after Israel demolished four houses in East Jerusalem and after a bombing of Gaza in which three Palestinians were killed.

There are neighbourhood effects in which upheaval in one country causes a domino effect in others. However, this starting point for a process of democratization is full of minefields. People will no longer be convinced that the only choice is between the stability and security of a dictator and the danger of Islamic extremism. Mao Zedong's old motto is pertinent: 'There is great chaos under heaven-the situation is

55) Mohammed A. Bamyeh, "Arab Revolutions and the Making of a New Patriotism." Orient. http://redchannels.org/writings/RC001/pdf/Furnaces_RC001.pdf.

56) Dignity expressed by different evocable: sharaf ('honour', 'virtue') as in Wael Ghonaim's letter in his Facebook account, 'All of Egypt is demanding honor' (Alexander, 2011, p. 7).

57) The regimes of Augusto Pinochet of Chile as well as of the Shah of Iran, Mohamed Reza Pahlavi, used to be called moderate. 
excellent.' For the immediate future, we should expect many difficult moments and a lot of negotiation with the military authority that has taken power in Egypt. Seen in this light, there are three issues at stake in the next phase.

The first issue is the extent to which opposition elites will unify around their basic claim in the face off with the military elite. In all countries undergoing turmoil, the army plays an important role, but its nature varies in each country. ${ }^{58)}$ The question to be posed now is: Would the army shift from being part of a regime to a formal institution obliged by constitutional provision and obligations to help in the formation and transition to a democratic state? So far armies in Yemen, Libya and Syria are embedded within the power structures, within ruling elites, whose commanders are part of the family of the rulers.59) The armies in Egypt and Syria have established an alliance with the new emerging capitalists. In essence, however, the soldiers often reflect socio-economically the mass of the population. As in the case of Latin America, one of the main challenges to democratic state-building processes has been the enforcement of civilian control over the military. Varas highlights the importance of the professionalization and de-politicization of the army and shows in this regard many trajectories in different regions of Latin America. ${ }^{60)}$

The second issue is the extent to which ethnicity, tribalism and

58) Yezid Sayigh, "The Role of the Army in the Arab Uprisings," (paper presented at the Centre for Mediterranean, Middle East and Islamic Studies, Athens, Greece, May 4, 2011).

59) Ibid.

60) A. Varas, Democratic Transitions and the Latin American Military ( ARI Thematic Studies, 2011). 
sectarianism will obstruct the political reform/revolutions. It is clear that wherever there are such divisions (Bahrain, Yemen, Syria and Libya), the revolution is yet undelivered. While this is a real issue, sometimes it is just a proclaimed one by the regime in order to disqualify the people's claims (the Syrian or Bahraini cases). The case of Lebanon is a very difficult one, where the primary allegiance of the population is to their sect and not to the state.

The third issue emerges after the overthrow of a certain regime, where old differences that had been set aside have come to the fore again-differences of class and ideology, all of which affect the vision of what a just society should be. The major question is the extent to which al-Nahda and the Muslim Brotherhood movements can deepen and consolidate their moderate stances, which are based on respecting the principles of democracy and pluralism, as often expressed by their leaders Sheikh Rashid Ghannouchi and Mahmoud Hussein Ahman. It is now known that inside these movements there are many trends ranging from those that are close to a Turkish model and those that reflect conservative Salafists. Scholars such as Burgat and Tammam note that the former trend is much stronger than the latter, and this affords hope that the process of democratization will accompany personal freedom. ${ }^{61)}$

61) F. Burgat, "Un Changement islamiste dans la Continuité: Salafistes contre Frères Musulmans," Le Monde Diplomatique, June 2010, and Hossam Tammam, Salafazed Moslim Brotherhood (Alexandria: Alexandria Library, 2010). 


\section{Works Cited}

Abaza, Mona. "On recent social protests in Egypt: a success story in spite of the absence of political parties." Sari Hanafi, ed. The state of exception and resistance in the Arab world. Beirut: Center for Arab Unity Studies, 2010. [in Arabic].

Agamben, G. Homo sacer. Sovereign power and bare life. Stanford, CA: Stanford University Press, 1998.

Amar, P. Why Mubarak is out February 1, 2011. Posted by bullybloggers in Current Affairs, 2011.

Bakhtin, M. Rabelais and his world. Bloomington, IA: Indiana University Press, 1984.

Bamyeh, Mohammed A. "Arab revolutions and the making of a new patriotism." Orient. 2011. http://redchannels.org/writings/RC001/pdf/Furnaces_ RC001.pdf.

Banyas, Mohamed. "Tharwret al-kalimat" [Revolution of words]. Majallat al-dirast al-falastiniyya, 88(2011): pp56-62. [in Arabic].

Barbin, J.L.S. "The Arab Spring and demography: the revolutionary power of youth.” 2011. http://en.qantara.de/The-Revolutionary-Power-of-Youth/ 16590c16844i0p/index.html/.

Bayat, Asef, "Egypt, and the post-Islamist Middle East." Open Democracy, accessed February 8, 2011, http://www.opendemocracy.net/asef-bayat/egypt-andpost-islamistmiddle-east/.

Boniface, P. et al. "Finkielkraut anxieux face à la perspective d'une Egypte démocratique." Institution de Relation internationales et stratégiques, 8 February 2011, http://www.iris-france.org/informez-vous/blog_pascal_ boniface_article. hp?numero $=46 /$.

Bouazizi, Mohsen. "Sociology of the indifference: from indifference to the free aggression in Tunisia." Sari Hanafi, ed. The state of exception and resistance in the Arab world. Beirut: Center for Arab Unity Studies, 2010. [in Arabic].

Bourdieu, P. Acts of resistance: against the tyranny of the market. New York, NY: New Press,1999. 
Bradawil, Fadi. "Ufūl al-Ikti'āb: mulāḥaẓātān hawla al-thawrāt al-'arabīy ah al-rāhinah" [Two notes about the Arab revolutions]. Majallat al-Dirasat al-Filastı $n$ ly ah, 88(2011), pp63-68. [in Arabic].

Burgat, F. "Un Changement islamiste dans la continuité: Salafistes contre Frères musulmans." Le Monde diplomatique, June(2010).

Challand, B. Palestinian civil society: foreign donors and the power to promote and exclude. London: Routledge, 2009.

Che Guevara. "Message to the Tricontinental" [April 1967]. Resurrecting a revolutionary cinema. The hour of the furnaces. Accessed 5 December 1981. Available from: http://redchannels.org/writings/RC001/pdf/ Furnaces_RC001.pdf/.

Clément, F. "Élections ouvrières: entre fraude et chasse aux 'Frères masqués." E. Klaus and C. Hassabo, eds. Chroniques égyptiennes. Cairo: Cedej, 2007.pp 59-86.

Courbage, Y. and Todd, E. "Le rendez-vous des civilizations". Y.Courbage and E. Todd, eds. A convergence of civilizations: the transformation of Muslim societies. New York, NY: Columbia University Press, 2007.

Dalmasso, E. and Cavatorta, F., n.d. Jadaliyya. http:/www.jadaliyya.com/pages/index/ 2365/the-never-ending-story_protests-and-constitutions/.

Debray, R. Cours de mediologiegenerale. Paris: Gallimard, 1991.

Dhillon, Navtej and Yousef, Tarik. Generation in waiting: the unfulfilled promise of young people in the Middle East. Brookings Institution Press, 2011.

Duboc, M., 2011. La contestation sociale en Égypte depuis 2004-précarisation et mobilization locale des ouvriers de l'industrie textile. RevueTiers monde, numbero hors series.

Economist Intelligence Unit. Spring tide or will the Arab risings yield democracy, dictatorship or disorder? Accessed 5 July 2011, http://pages.eiu.com/rs/eiu2/images/Arab_Spring_Tide_Whitepaper_Jun2011.pdf.

Eickelman, D.F. "The Arab 'street' and the Middle East's democracy deficit." Naval War College Review 40, no.4 (2002), pp39-48.

El Oifi, Mohammed. "Influence without power: Aljazeera and the Arab public sphere." M. Zayeni, ed. The Al Jazeera phenomenon: critical 
perspectives on new Arab media. Boulder, CO: Paradigm, 2005.

El Oifi, Mohammed. "L'opinion publique arabe entre logiques étatiques et solidarities transnationales." Raisons politiques 3, no.19 (2005), pp45-62.

Hanafi, Sari. "Framing Arab socio-political space: state governmentality, governance and non-institutional protestation." Contemporary Arab Affairs, 3 no.2 (2010),pp 148-162.

Hanafi, Sari, ed. The state of exception and resistance in the Arab world. Beirut: Center for Arab Unity Studies, 2010. [in Arabic].

Hroub, Khaled, 2011. Arab third way: beyond dictators and Islamists. Open Democracy, accessed 9 February 2011. http://www.opendemocracy.net/ khaled- hroub/arab-third-waybeyond-dictators-and-islamists/. http://www.cemmis.edu.gr/images/multimedia/lecture_sayigh_role_army _arab\%20uprisings_transcript.pdf/.

Kabbanji, J. "Why have the Tunisian and Egyptian revolutions surprised us?" Iḍâfāt: Arab Journal of Sociology, 14(2011), pp9-31. [in Arabic].

Khairi, Amina. al-Hayat, 7 February 2011a.

Khairi, Amina. al-Hayat, 9 February 2011b.

Khouri, Rami. Drop the Orientalist term 'Arab Spring'. http://www.dailystar. com.lb/Opinion/Columnist/2011/Aug-17/Drop-the-Orientalist-term-ArabSpring.ashx\#ixzz1VGW806O8/.

Al-Khoury, Tania. "Kulonashohoud 'ayan: rabii al-Arab bi al-sowarwa al-harb al-Ilekitroniyya" [We are all witness: the Arab Spring in image and the cyberwar]. Majallat al-dirast al-falastiniyya, 88(2011), pp122-132. [in Arabic].

Longuenesse, E. Professions et société au Proche-Orient. Déclin des élites et crise des classes moyennes. Rennes: Presses Universitaires de Rennes, 2007.

Al-Madini, Tawfic. "Rabii al-thawrat al-dimocratiyya al-Arabiyya" [The Spring of the Arab revolutions]. al-mustaqbal al-Arabi(2011). [in Arabic].

Marktanner, M. "The economic causes of the Arab uprising." Paper presented at a workshop at the American University of Beirut (AUB), Beirut, Lebanon, 2011.

Mbembe, A. "Necropolitics.” Public Culture, 15 no.1 (2003), pp11-40. 
Muasher, Marwan. Jordan's proposed constitutional amendments - a first step in the right direction. The Carnegie Middle East Program, 2011.

Reynolds, J. Emergency, governmentality, and the Arab Spring. Jadaliyya, 14 August 2011.

Sayigh, Yezid. "The role of the army in the Arab uprisings." Paper presented at the Centre for Mediterranean, Middle East and Islamic Studies. Athens, Greece, 4 May 2011. Security Sector Reform, n.d. http://www.arabreform.net/spip.php?article4629/.

Syrian Observatory of Human Rights. Available from: http://www.syriahr.com/.

Tammam, Hossam, 2010. Salafazed Moslim Brotherhood. Alexandria: Alexandria Library. [in Arabic].

Todorov, T. "La tyrannie de l'individu." Le Monde, 18. 28 March 2011.

Touraine, A. Critique of modernity. Oxford: Basil Blackwell, 1995.

United Nations Development Programme (UNDP). Arab human development report. Washington, DC: UNDP, 2009.

United Nations Economic and Social Commission on Western Asia (ESCWA), 2012. Population in the Arab World declines. http://www.alarabiya. net/articles/ 2010/07/27/115002.html.

Varas, A. Democratic transitions and the Latin American military. ARI Thematic Studies, 2011.

논문 투고일자: 2012. 4. 19

- 심사(수정)일자: 2012. 4. 28

- 게재 확정일자: 2012. 5. 11 


\title{
Abstract
}

\section{The Arab Revolutions: The Emergence of a New Political Subjectivity}

\author{
Sari Hanafi \\ (American University of Beirut, Beirut, Lebanon)
}

Since late 2010, the Arab World has witnessed regime changes in Tunisia, Egypt and Libya; and revolts by Arab citizens are still underway in Syria, Bahrain and Yemen, along with reform initiatives at different levels. These processes cannot be accurately be described by Orientalist terms such as 'Arab Spring', 'Arab unrest' or the 'Facebook Revolution', where such categorizations fail to account for the radical transformation in politics and values that the Arab World is undergoing and the significance that resides in the confluence of social and democratic demands. The ultimate fate of these popular uprisings remains in the balance, but it is all too clear that they have produced the most dramatic changes in the region since the mid-twentieth century which marked the end of the colonial era. This article aims to elucidate the import of term 'the people' and to whom it applies in the popular slogan: 'The people want the overthrow of the regime' (al-sha'b yurı̄ isqāt al-nizāam). It aims to identify the actors involved in the revolution, particularly the youth and participants among the labour movement. Through this analysis the study explores the new political subjectivity ushered in by these revolutions, in the specific form of individuality, or what is termed here reflexive individualism. This individualism, which is different from the neoliberal concept, is not a straightforward one predicated on anti-patriarchal authority, anti-tribe, anti-community or anti-political party sentiments. The political subjectivity of the individuals who have taken part is formed and shaped both within and across the shadowy edges of political institutions and their production of legitimacy and knowledge. 
74 Sari Hanafi

\section{Key Words}

Reflexive Individualism, Arab Revolutions, Arab Spring, Labour Movement, Islamism, Youth, Non-governmental Organizations(NGOs), Political Parties 